\title{
Drug delivery approaches for breast cancer
}

This article was published in the following Dove Press journal:

International Journal of Nanomedicine

24 August 2017

Number of times this article has been viewed

\author{
Santosh Kumar Singh' \\ Shriti Singh ${ }^{2}$ \\ James W Lillard Jr' \\ Rajesh Singh' \\ 'Department of Microbiology, \\ Biochemistry and Immunology, \\ Morehouse School of Medicine, \\ Atlanta, GA, USA; ${ }^{2}$ Department of \\ Kriya Sharir, Institute of Medical \\ Sciences, Banaras Hindu University, \\ Varanasi, India
}

\begin{abstract}
Breast cancer is one of the most common cancers affecting women worldwide. The controlled release of drugs to the precise site of the disease using a nanocarrier vehicle increases the therapeutic efficiency of the drugs. Nanotechnology-based approaches used to endorse clinical improvement from a disease also help to understand the interaction of malignant cells with their microenvironment. Receptor-based targeting is another approach for drug delivery which is undergoing clinical trials. Nanoparticles (NPs) delivery has been proven to promise high loading capacity, less toxicity, and stability of the drugs or biomolecules compared to traditional chemotherapeutic drugs. The goal of this review is to present the current problems of breast cancer therapy and discuss the NP-based targeting to overcome the hurdles of conventional drug therapy approach.
\end{abstract}

Keywords: breast cancer, nanoparticles, drug delivery systems

\section{Introduction}

Breast cancer is one of the most common cancers affecting women worldwide. In 2016, a total of 246,660 new cases of breast cancer and $14 \%$ of deaths due to breast cancer were reported in the US. ${ }^{1}$ The majority of the deaths from breast cancer are due to its drug resistance and potential of metastasis to distant organs, such as the lymph nodes, bone, lung, and liver. ${ }^{2,3}$ It is well known that an ATP-binding cassette (ABC) family protein plays an important role in drug resistance in multiple malignancies, and its higher expression is proportional to higher resistance towards chemotherapy. Multidrug resistance (MDR) due to high expression of proteins such as P-glycoprotein (P-gp/ABCB1), ABCG2, and BCRP is a major hurdle in breast cancer prognosis and treatment. Although recent advances in immunotherapy have been made with the development of small molecules, proteins, and peptides, controlled-release drug delivery and targeting are still not achieved.

As indicated, the majority of the deaths from breast cancer are due to its potential of metastasis to distant organs. ${ }^{2,3}$ There are several pathways involved in the modulation of breast cancer and its progression to metastasis. ${ }^{4-6}$ There has been progress made in understanding the biological behavior of estrogen receptors (ERs), progesterone receptors (PRs), and human epidermal growth factor receptor 2 (HER-2) for multiple subtypes of breast cancer. Nanoparticles (NPs) carrying anticancer agents can be delivered actively or passively to targeted tumor to serve in diagnosis and treatment of breast cancer. NPs have multifunctional properties. In recent years, controlled release of therapeutic compounds from NPs has been achieved to determine the efficacy of the drug and to overcome MDR.

We previously reported the use of nanocapsules, nanospheres, and polymeric NPs for drug delivery, in which the drugs were physically and uniformly dispersed. ${ }^{7}$ NPs size and distribution are measured by photon correlation spectroscopy and verified 
by scanning or transmission electron microscopy (TEM) to determine the diameter of the particles. ${ }^{4}$ This technology of drug delivery using nanometer-sized particles could be the major therapeutic approach for future cancer patients. A recent progress in drug delivery technology is the design of surface-modified NPs that can improve the poor specificity and toxicological problems of antitumor therapy and act as a major therapeutic approach for patients. Primarily, the drug carriers used during the treatment act slowly for a longer period of time using specific stimuli. The conventional chemotherapeutic drugs affect both normal and cancer cells, whereas NP-coated drugs accumulate in tumors through enhanced permeability. ${ }^{8}$

The application of NPs in medicine has enabled the development of nano-formulated drug delivery approach. There are several types of drug carriers commonly available such as polymeric dendrimers, micelles, microspheres, liposomes, quantum dots (QDs), nanoemulsions, gold nanoparticles (GNPs), and hydrogels, which require various methods of drug attachment including encapsulation, covalent binding, and adsorption. ${ }^{9,10}$ For example, lipid-based NPs can activate the secretion of glucagon-like peptide 1 for the treatment of human diabetes mellitus type-2. ${ }^{11}$ Several other applications of nanomaterials such as carbon nanotubes, silver, and silica nanocarriers have been promoted in the biomedical field, and these nanomaterials are used during the treatment of various neurological and cancer diseases. ${ }^{12-14}$ Recently, nextgeneration nano-formulated platinum-based drug delivery has been used in clinics for cancer. ${ }^{15}$

The receptor (HER-2, epidermal growth factor receptor [EGFR], vascular endothelial growth factor receptor [VEGFR], insulin-like growth factor I receptor [IGF-IR])based targeting is the approach which is correlated with the breast tumorigenesis and is undergoing clinical trials (Phases II and III). ${ }^{16}$ Among them, the most common type of breast cancer, which affects one in five women, is HER2-positive breast cancer caused due to the overexpression of HER-2 on the surface of the breast tumor and characterized by poor prognosis and aggressive growth. An overview of the ongoing breast cancer clinical trials based on targeted therapy and chemotherapy drugs is presented in Table 1. Moreover, antibody-NP conjugates also facilitate the loading of higher drug concentrations for targeted delivery. For example, liposomes formulated with the monoclonal antibodies

Table I Overview of ongoing breast cancer clinical trials based on targeted and chemotherapeutic drugs

\begin{tabular}{|c|c|c|c|c|c|}
\hline Therapeutic agents & Target cancer subtypes & $\begin{array}{l}\text { Clinical } \\
\text { trial phases }\end{array}$ & Type & Status & $\begin{array}{l}\text { Trail ID reference } \\
\text { (ClinicalTrails.gov) }\end{array}$ \\
\hline Trastuzumab & $\begin{array}{l}\text { HER-2-positive and locally } \\
\text { advanced/metastatic breast cancer }\end{array}$ & $\begin{array}{l}\text { Phase III, } \\
\text { Phase II }\end{array}$ & $\begin{array}{l}\text { Biomarker/laboratory } \\
\text { analysis, treatment }\end{array}$ & Active & MM-302-02-02-03 \\
\hline $\begin{array}{l}\text { Neratinib plus capecitabine vs } \\
\text { lapatinib plus capecitabine }\end{array}$ & $\begin{array}{l}\text { HER-2-positive metastatic breast } \\
\text { cancer }\end{array}$ & Phase III & Treatment & Active & PUMA-NER-I30I \\
\hline $\begin{array}{l}\text { Talazoparib (BMN 673), a PARP } \\
\text { inhibitor }\end{array}$ & $\begin{array}{l}\text { Advanced and/or metastatic } \\
\text { breast cancer patients with BRCA } \\
\text { mutation }\end{array}$ & Phase III & Treatment & Active & $673-301$ \\
\hline Fulvestrant and/or anastrozole & $\begin{array}{l}\text { Postmenopausal patients } \\
\text { with stage II-III breast cancer } \\
\text { undergoing surgery }\end{array}$ & Phase III & Treatment & Active & A0III06 \\
\hline Olaparib & $\begin{array}{l}\text { Triple-negative nonmetastatic } \\
\text { breast cancer }\end{array}$ & Phase III & $\begin{array}{l}\text { Biomarker/laboratory } \\
\text { analysis, natural } \\
\text { history/epidemiology, } \\
\text { treatment }\end{array}$ & Active & NSABP-B-55 \\
\hline $\begin{array}{l}\text { Carboplatin and paclitaxel with } \\
\text { or without veliparib (ABT-888) }\end{array}$ & $\begin{array}{l}\text { ER2-negative metastatic or locally } \\
\text { advanced breast cancer }\end{array}$ & Phase III & Treatment & Active & $M|2-9| 4$ \\
\hline $\begin{array}{l}\text { Palbociclib (PD-033299I) + } \\
\text { letrozole vs placebo + letrozole }\end{array}$ & $\begin{array}{l}\text { ER-positive/HER-2-negative } \\
\text { advanced breast cancer }\end{array}$ & Phase III & $\begin{array}{l}\text { Biomarker/laboratory } \\
\text { analysis, treatment }\end{array}$ & Active & A548I027 \\
\hline $\begin{array}{l}\text { Platinum-based or capecitabine } \\
\text { chemotherapy }\end{array}$ & $\begin{array}{l}\text { Triple-negative basal-like breast } \\
\text { cancer }\end{array}$ & Phase III & $\begin{array}{l}\text { Biomarker/laboratory } \\
\text { analysis, treatment }\end{array}$ & Active & EAII3I \\
\hline $\begin{array}{l}\text { Doxorubicin hydrochloride and } \\
\text { cyclophosphamide followed } \\
\text { by paclitaxel with or without } \\
\text { carboplatin }\end{array}$ & Triple-negative breast cancer & Phase III & $\begin{array}{l}\text { Biomarker/laboratory } \\
\text { analysis, treatment }\end{array}$ & Active & NRG-BR003 \\
\hline $\begin{array}{l}\text { Margetuximab plus } \\
\text { chemotherapy vs trastuzumab } \\
\text { plus chemotherapy }\end{array}$ & $\begin{array}{l}\text { HER-2-positive metastatic breast } \\
\text { cancer }\end{array}$ & Phase III & Treatment & Active & CP-MGAH22-04 \\
\hline
\end{tabular}


Table I (Continued)

\begin{tabular}{|c|c|c|c|c|c|}
\hline Therapeutic agents & Target cancer subtypes & $\begin{array}{l}\text { Clinical } \\
\text { trial phases }\end{array}$ & Type & Status & $\begin{array}{l}\text { Trail ID reference } \\
\text { (ClinicalTrails.gov) }\end{array}$ \\
\hline $\begin{array}{l}\text { Pembrolizumab (MK-3475) vs } \\
\text { single-agent chemotherapy }\end{array}$ & $\begin{array}{l}\text { Metastatic triple-negative breast } \\
\text { cancer }\end{array}$ & Phase III & Treatment & Active & $3475-119$ \\
\hline $\begin{array}{l}\text { Pembrolizumab (MK-3475) plus } \\
\text { chemotherapy vs placebo plus } \\
\text { chemotherapy }\end{array}$ & $\begin{array}{l}\text { Metastatic triple-negative breast } \\
\text { cancer }\end{array}$ & Phase III & $\begin{array}{l}\text { Biomarker/laboratory } \\
\text { analysis, treatment }\end{array}$ & Active & $3475-355$ \\
\hline $\begin{array}{l}\text { Trastuzumab in treating } \\
\text { leptomeningeal metastases }\end{array}$ & HER-2-positive breast cancer & $\begin{array}{l}\text { Phase II, } \\
\text { Phase I }\end{array}$ & $\begin{array}{l}\text { Biomarker/laboratory } \\
\text { analysis, treatment }\end{array}$ & Active & $\mathrm{NU} 10 \mathrm{C03}$ \\
\hline $\begin{array}{l}\text { BBI608 administered with } \\
\text { paclitaxel }\end{array}$ & Advanced malignancies & $\begin{array}{l}\text { Phase II, } \\
\text { Phase I }\end{array}$ & Treatment & Active & BBI608-20I \\
\hline $\begin{array}{l}\text { Imiquimod, cyclophosphamide, } \\
\text { and radiation therapy }\end{array}$ & $\begin{array}{l}\text { Breast cancer with skin } \\
\text { metastases }\end{array}$ & $\begin{array}{l}\text { Phase II, } \\
\text { Phase I }\end{array}$ & Treatment & Active & NYU I I-00598 \\
\hline $\begin{array}{l}\text { Dovitinib lactate in combination } \\
\text { with anastrozole, exemestane, } \\
\text { or letrozole }\end{array}$ & $\begin{array}{l}\text { Hormone-receptor-positive } \\
\text { metastatic breast cancer }\end{array}$ & $\begin{array}{l}\text { Phase II, } \\
\text { Phase I }\end{array}$ & $\begin{array}{l}\text { Biomarker/laboratory } \\
\text { analysis, treatment }\end{array}$ & Active & $2010-535$ \\
\hline $\begin{array}{l}\text { Tyrosine kinase inhibitor } \\
\text { PLX3397 and eribulin mesylate }\end{array}$ & Triple-negative breast cancer & $\begin{array}{l}\text { Phase II, } \\
\text { Phase I }\end{array}$ & $\begin{array}{l}\text { Biomarker/laboratory } \\
\text { analysis, treatment }\end{array}$ & Active & $|275|$ \\
\hline $\begin{array}{l}\text { Triciribine phosphate, paclitaxel, } \\
\text { doxorubicin hydrochloride, and } \\
\text { cyclophosphamide }\end{array}$ & Stage IIB-IV breast cancer & $\begin{array}{l}\text { Phase II, } \\
\text { Phase I }\end{array}$ & Treatment & Active & $2011-269$ \\
\hline $\begin{array}{l}\text { GDC- } 0810 \text { single agent or in } \\
\text { combination with palbociclib } \\
\text { and/or a luteinizing hormone- } \\
\text { releasing hormone agonist }\end{array}$ & $\begin{array}{l}\text { Locally advanced or metastatic } \\
\text { ER-positive breast cancer }\end{array}$ & $\begin{array}{l}\text { Phase II, } \\
\text { Phase I }\end{array}$ & $\begin{array}{l}\text { Biomarker/laboratory } \\
\text { analysis, treatment }\end{array}$ & Active & GO29642 \\
\hline LEEOI I, BYL7I9, and letrozole & $\begin{array}{l}\text { Advanced ER-positive breast } \\
\text { cancer }\end{array}$ & $\begin{array}{l}\text { Phase II, } \\
\text { Phase I }\end{array}$ & $\begin{array}{l}\text { Biomarker/laboratory } \\
\text { analysis, treatment }\end{array}$ & Active & CLEE0IIX2I 07 \\
\hline $\begin{array}{l}\text { Nivolumab combined with } \\
\text { ipilimumab }\end{array}$ & $\begin{array}{l}\text { Advanced or metastatic solid } \\
\text { tumors }\end{array}$ & $\begin{array}{l}\text { Phase II, } \\
\text { Phase I }\end{array}$ & Treatment & Active & CA209-032 \\
\hline $\begin{array}{l}\text { MLNOI } 28 \text { in combination with } \\
\text { exemestane or fulvestrant }\end{array}$ & $\begin{array}{l}\text { ER/PR-positive metastatic breast } \\
\text { cancer }\end{array}$ & $\begin{array}{l}\text { Phase II, } \\
\text { Phase I }\end{array}$ & $\begin{array}{l}\text { Biomarker/laboratory } \\
\text { analysis, treatment }\end{array}$ & Active & C3I00I \\
\hline $\begin{array}{l}\text { Romidepsin and paclitaxel } \\
\text { albumin-stabilized nanoparticle } \\
\text { formulation }\end{array}$ & $\begin{array}{l}\text { Metastatic inflammatory breast } \\
\text { cancer }\end{array}$ & $\begin{array}{l}\text { Phase II, } \\
\text { Phase I }\end{array}$ & Treatment & $\begin{array}{l}\text { Temporarily } \\
\text { closed }\end{array}$ & 13C.387 \\
\hline $\begin{array}{l}\text { Ruxolitinib phosphate and } \\
\text { trastuzumab }\end{array}$ & $\begin{array}{l}\text { Metastatic HER-2-positive breast } \\
\text { cancer }\end{array}$ & $\begin{array}{l}\text { Phase II, } \\
\text { Phase I }\end{array}$ & Treatment & Active & AAAMI906 \\
\hline $\begin{array}{l}\text { Gemcitabine hydrochloride, } \\
\text { trastuzumab, and pertuzumab }\end{array}$ & $\begin{array}{l}\text { HER-2-positive metastatic breast } \\
\text { cancer }\end{array}$ & $\begin{array}{l}\text { Phase II, } \\
\text { Phase I }\end{array}$ & Treatment & Active & MCC- 17656 \\
\hline $\begin{array}{l}\text { PI3K inhibitor BYL7 I9 and } \\
\text { paclitaxel albumin-stabilized } \\
\text { nanoparticle formulation }\end{array}$ & $\begin{array}{l}\text { HER-2-negative stage III or IV } \\
\text { breast cancer }\end{array}$ & $\begin{array}{l}\text { Phase II, } \\
\text { Phase I }\end{array}$ & $\begin{array}{l}\text { Biomarker/laboratory } \\
\text { analysis, treatment }\end{array}$ & Active & CBYL7I9XUS06T \\
\hline
\end{tabular}

Abbreviations: HER-2, human epidermal growth factor receptor 2; PARP, poly (ADP-ribose) polymerase; ER2, estrogen receptor 2; ER, estrogen receptor; PR, progesterone receptor.

act against tumor cell antigens. ${ }^{17}$ Nanocarrier-based and clinically approved therapeutic drug conjugates used to target metastatic breast cancer are shown in Tables 2 and 3. Targeted drug nanocarriers could replace the current method of treatment of chemoresistant tumor cells and cure cancer. In this review, we discuss the various drug delivery platforms (systemic, localized, and receptor-based) used for the model of breast cancer therapy (Figure 1).

\section{Systemic drug delivery approaches}

Nanocarrier-based drug delivery systems for chemotherapeutic drugs act efficiently on multiple malignant sites. The most common drug delivery approaches are based on organic and inorganic particles. The organic particles used for drug delivery application are micelles, liposomes, polymers, dendrimers, and nanogels. They have versatile surface building blocks for efficient endocytosis and loading. NPs have a multifunctional surface-modifying property that directs the cell to the tumor vasculature. The technology of encapsulating chemotherapeutic drugs using a nano-scale device is the best approach with regard to decreased side effects and improved bioavailability of drugs for breast cancer. While emerging technologies of systemic drug delivery using NPs promise early treatment of breast cancer, at present, limited options 
Table 2 Nanocarrier-based therapeutic drug conjugates to target metastatic breast cancer

\begin{tabular}{|c|c|c|c|}
\hline Nanoparticle carrier composition & Therapeutics & Action & References \\
\hline Polyethylene glycol-poly(d,I-lactide-co-glycolide) & Paclitaxel + lonidamine & EGFR & 18 \\
\hline $\begin{array}{l}\text { Poly }(\mathrm{N} \text {-methyldietheneaminesebacate)-co- } \\
\text { [(cholesteryloxocarbonylamido ethyl) methyl } \\
\text { bis (ethylene) ammonium bromide] sebacate }\end{array}$ & Paclitaxel + siRNA & $\begin{array}{l}\text { Downregulation of } \mathrm{Bcl}-2 \text { and increased } \\
\text { cytotoxicity in MDA-MB-23I cells }\end{array}$ & 19 \\
\hline Bio-nanocapsule/liposome & $Z_{\text {HER-2 }}-B N C+$ siRNA & $\begin{array}{l}\text { Gene silencing and protein knock down } \\
\text { in HER-2-expressing breast cancer cells }\end{array}$ & 20 \\
\hline $\begin{array}{l}\text { Polyethylene glycol-block-poly(N-hexyl stearate } \\
\text { I-aspartamide) }\end{array}$ & Doxorubicin + wortmannin & Passive, metastatic breast cancer & 21 \\
\hline Polyethylene glycol-liposome & Quercetin+vincristine & Passive, metastatic breast cancer & 22 \\
\hline Cationic, anionic polyethylene glycol-liposome & siRNA + doxorubicin & Passive, metastatic breast cancer & 23 \\
\hline $\begin{array}{l}\mathrm{N} \text {-(2-hydroxypropyl) methacrylamide } \\
\text { copolymer }\end{array}$ & Trastuzumab + PKII66 & Active, HER-2 breast cancer & 24 \\
\hline
\end{tabular}

Abbreviations: EGFR, epidermal growth factor receptor; BNC, bio-nanocapsule; HER-2, human epidermal growth factor receptor 2.

are available to the patients with metastatic breast cancer. Based on nanocarrier platforms, the most relevant strategy for precise site targeting in drug-resistant breast tumor cells is shown in Figure 2.

\section{Organic drug delivery approaches Micelles}

Polymeric micelles (PMs) are colloidal particles prepared from conjugates of water-soluble polymers with phospholipids or long-chain fatty acids and other surfactants. Micelles are used for the delivery of water-insoluble chemotherapeutic drugs. They were first proposed by Paul Ehrlich for targeted drug delivery to diseased cells. Micelles accumulate at poorly vascularized tumors and enhance permeability and retention, and increase the half-life of anticancer agents. ${ }^{44}$ They have been shown to overcome P-gp efflux, act through receptor-mediated endocytosis, and increase intracellular drug concentration with enhanced cytotoxicity in MCF-7/ doxorubicin-resistant cells. ${ }^{45,46}$ Moreover, fabricated immune micelles (antibodies bound to the surface of micelles) were also used in breast adenocarcinomas. Treatment of HER-2-positive breast cancer was performed with antiHER-2 monoclonal antibody (mAb), fabricated with antibody-conjugated lysosomal P (LA-co-TMCC)-g-PEGfuran micelles. ${ }^{47}$ Use of anti-HER-2 antibody complex micellar formulation in HER-2-positive and HER-2-negative cells has shown high efficacy of taxol compared to simple lipid-based protein. ${ }^{48}$ In another study of the use of paclitaxel

Table 3 Additional clinically approved chemotherapeutic drug combination for metastatic breast cancer prevention

\begin{tabular}{|c|c|c|c|}
\hline Agents & Drug combinations & Action & References \\
\hline \multirow[t]{3}{*}{ Monoclonal antibodies } & $\begin{array}{l}\text { Trastuzumab + doxorubicin + cyclophosphamide; } \\
\text { trastuzumab + epirubicin + cyclophosphamide }\end{array}$ & $\begin{array}{l}\text { Improved overall survival and response rate, while } \\
\text { cardiomyopathy and hematological toxicity were observed }\end{array}$ & 16,25 \\
\hline & $\begin{array}{l}\text { Trastuzumab + paclitaxel; trastuzumab + } \\
\text { gemcitabine; trastuzumab + vinorelbine }\end{array}$ & Progression-free survival with hematological toxicity & 26 \\
\hline & Cituximab + cisplatin & $\begin{array}{l}\text { Improved response rate in TNBC with neutropenia and } \\
\text { dyspnea }\end{array}$ & 27 \\
\hline $\begin{array}{l}\text { Tyrosine kinase inhibitor } \\
\text { based }\end{array}$ & $\begin{array}{l}\text { Lapatinib + (capecitabine, paclitaxel, letrozole); } \\
\text { sunitinib + docetaxel; erlotinib + cisplatin + } \\
\text { gemcitabine }\end{array}$ & $\begin{array}{l}\text { Improved response rate and overall survival, but toxicity, } \\
\text { diarrhea, and skin rashes were the side effects }\end{array}$ & $28-32$ \\
\hline Anthracycline based & $\begin{array}{l}\text { Anthracycline-based doxorubicin + } \\
\text { cyclophosphamide; doxorubicin + fluorouracil; } \\
\text { epirubicin + fluorouracil/cyclophosphamide }\end{array}$ & $\begin{array}{l}\text { Improved response rate while related toxicity and no } \\
\text { significant difference in progression or survival were } \\
\text { observed }\end{array}$ & 33 \\
\hline Taxane based & $\begin{array}{l}\text { Doxorubicin + paclitaxel; doxorubicin + } \\
\text { docetaxel; capecitabine + docetaxel; } \\
\text { gemcitabine + paclitaxel }\end{array}$ & $\begin{array}{l}\text { Improved response rate, progression-free survival, and } \\
\text { relapse-free survival, but side effects such as cardiotoxicity, } \\
\text { hematological toxicity, and increased diarrhea were found }\end{array}$ & $34-38$ \\
\hline \multirow[t]{3}{*}{$\begin{array}{l}\text { Other chemotherapeutic } \\
\text { regimen combinations }\end{array}$} & Ixabepilone + capecitabine & $\begin{array}{l}\text { Improved response rate but peripheral neuropathy was } \\
\text { observed }\end{array}$ & 39 \\
\hline & $\begin{array}{l}\text { Cyclophosphamide }+ \text { methotrexate }+ \\
\text { fluorouracil }\end{array}$ & $\begin{array}{l}\text { Overall improved survival and relapse-free survival, but } \\
\text { loss of bone was a disadvantage }\end{array}$ & $40-42$ \\
\hline & Trastuzumab + lapatinib & $\begin{array}{l}\text { Improved patient survival, and overcome toxicity issue } \\
\text { with trastuzumab }\end{array}$ & 43 \\
\hline
\end{tabular}

Abbreviation: TNBC, triple-negative breast cancer. 


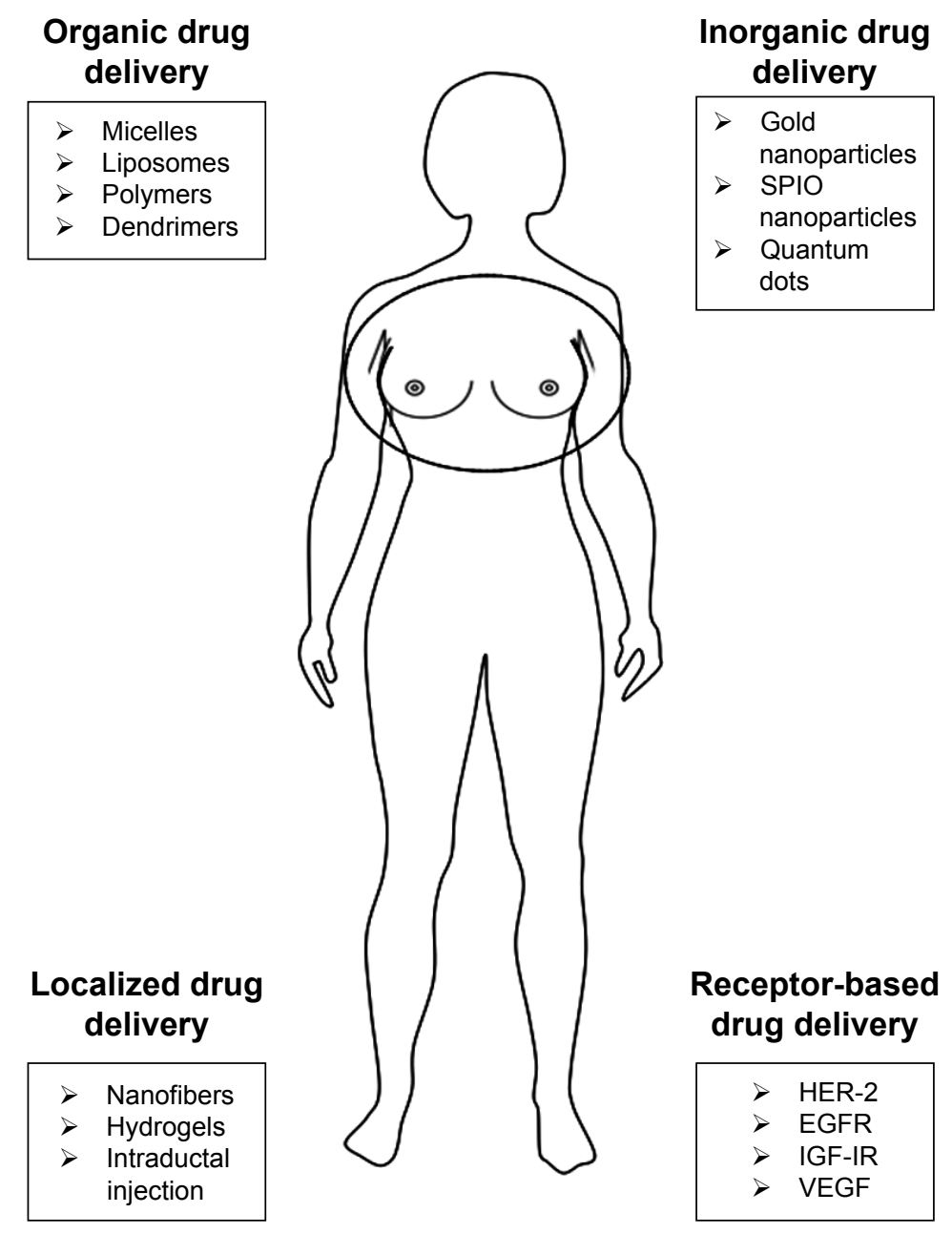

Figure I Drug delivery systems for breast cancer.

Abbreviations: SPIO, superparamagnetic iron oxide; HER-2, human epidermal growth factor receptor 2; EGFR, epidermal growth factor receptor; IGF-IR, insulin-like growth factor I receptor; VEGFR, vascular endothelial growth factor receptor.

PM formulation in metastatic breast cancer patients, the Genexol-PM response rate was observed to be $58.5 \%$ compared to plain drugs that are in clinical trial Phases I and II. However, in SK-BR-3 cells, antibody-decorated NPs have shown $53.4 \%$ and $38.6 \%$ higher cellular uptake than the plain micelles in Phases I and II, respectively. ${ }^{49}$

\section{Liposomes}

Liposomes are spherical vesicle microparticles that contain single or multiple bilayered membrane structures and were first described in 1965. ${ }^{8,50}$ Their size varies from 50-200 nm and they have a tendency to accumulate in tumor cells with an enhanced permeability and retention. Liposomes are classified based on size and composition and influenced by several factors such as bilayered fluidity, surface charge, surface hydration, and methods of preparation. ${ }^{51}$ Liposomes have been reported to encapsulate lipophilic and hydrophobic drugs which are stable, nontoxic, biocompatible, biodegradable, and non-immunogenic. ${ }^{52}$ Moreover, liposomes are reported to play a role in direct inhibition of P-gp by anionic membrane lipids. A previous study on Rhodamine retention using P-gp and BCRP substrate in breast cancer cell line MCF-7 showed that liposome encapsulation was increased in MCF-7/P-gp cells compared to MCF-7/wildtype cells. ${ }^{53}$ Liposomes are reported as an effective delivery system for siRNA- or oligonucleotide-based therapy, and liposome-based drug formulations are currently used in clinical protocols. ${ }^{54}$ The encapsulation of drugs in liposomes reduces the toxicity through biodistribution. The therapeutic application of liposomes as a drug carrier for the delivery of paclitaxel has also been evaluated in human ovarian cancer. ${ }^{55,56}$ Due to their small size and prolonged circulation, liposomes (including PEGylated liposomes) can provide protection from mononuclear phagocytes. PEGylated liposomes formulation with NPs coated on the surface using polyethylene glycol (PEG) improved the efficacy of drug 


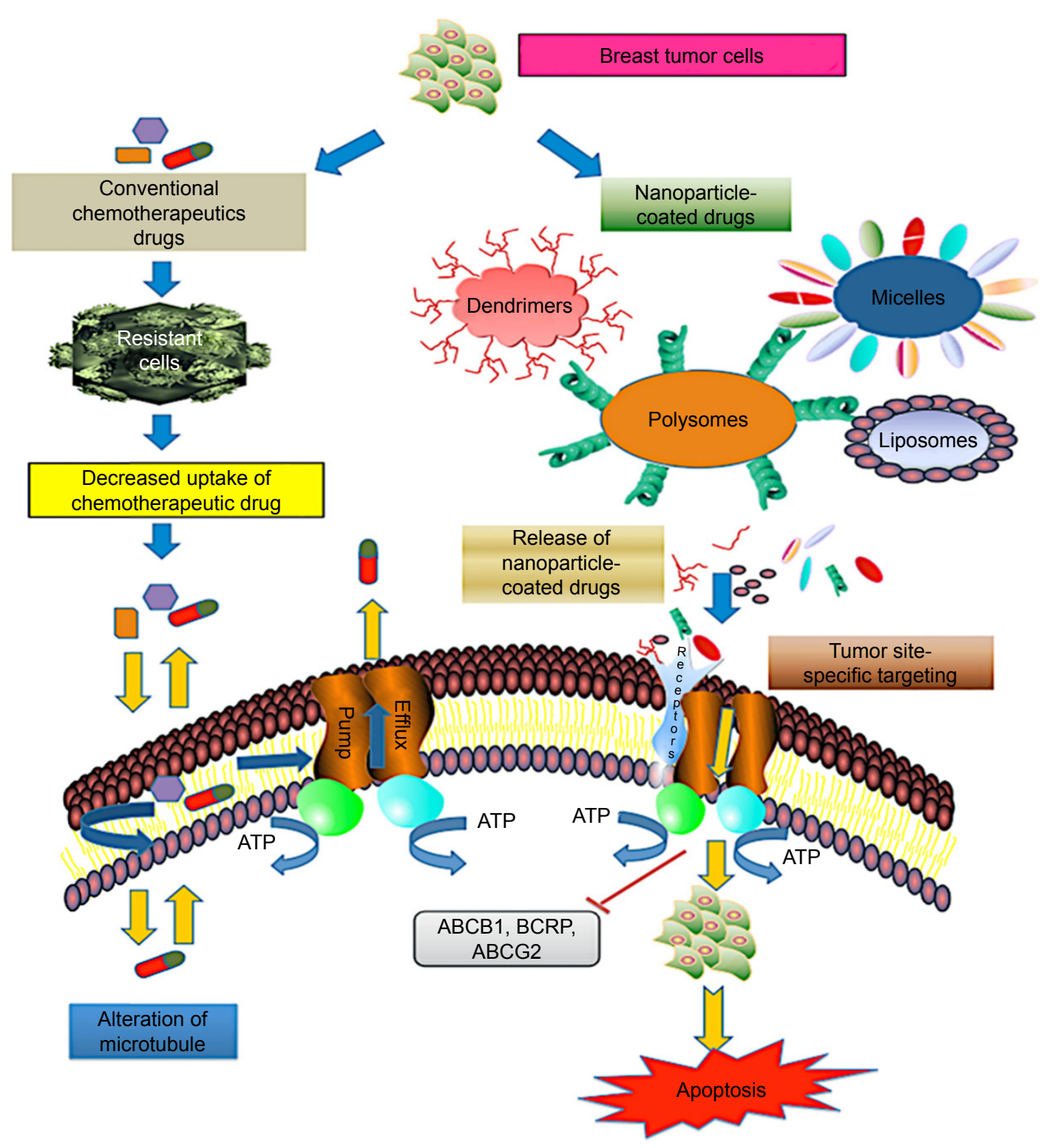

Figure 2 Schematic representation of nanoparticle-based drug delivery mechanism in drug-resistant breast cancer cells. The most common mechanism of drug efflux in cancer cells is mediated by $A B C$ transporters P-glycoprotein, BCRP, and ABCG2. Multidrug resistance protein consisting of nuclear-binding domain and transmembrane domain binds to the receptors on the surface of target tumor cells and functions in efflux of chemotherapeutic drugs such as taxol and anthracycline. However, delivery approaches using targeted drug nanocarriers (dendrimers, liposomes, micelles, polysomes) overcome the chemoresistance in tumor cells by activation of proapoptotic mediators, resulting in cell death.

Abbreviation: ABC, ATP-binding cassette.

delivery to target cells. ${ }^{57}$ Yang et al reported that PEGylated formulation of paclitaxel increased the half-life compared to conventional liposomes formulation. ${ }^{58}$ The combinations of doxorubicin and cyclophosphamide utilizing non-PEGylated liposomes were used for the treatment of metastatic breast cancer. ${ }^{59}$ Moreover, liposome-conjugated antibody that overexpresses the HER-2 has been developed and reported as delivering 22-fold more calcein to mammary epithelial cells. ${ }^{60}$ The synergistic effects of combined drug delivery of quercetin and vincristine through liposomes were reported for treatment of ER-negative breast cancer. ${ }^{61}$

\section{Polymers}

Polymeric NPs (size 3-200 $\mathrm{nm}$ ) that are formulated by binding a copolymer to a polymer matrix are widely used as drug delivery carriers. Polymers are classified as natural, synthetic, biodegradable, and nonbiodegradable forms. The most commonly used natural polymers are cellulose, chitosan, alginate, and gelatin, which are mildly immunogenic in nature. In addition, modified polymers with precise chemical composition increase the efficacy of site-specific targeting. Moreover, synthetic polymers such as poly- $\varepsilon$-caprolactone (PCL), poly-(lactic-co-glycolide), and polylactide (PLA) 
have a high rate of solubility and permeability. Such polymers are biocompatible and biodegradable with slow degradation rate, with good drug stability and release. Numerous polymer-drug conjugates, such as poly(d,1-lactide-coglycolide) (PLGA), PEG, dextran, and N-(2-hydroxypropyl) methacrylamide (HPMA), have been tested in drug delivery research. ${ }^{24}$ Chemotherapeutic drugs like paclitaxel, doxorubicin, camptothecins, and platinates have been clinically tested in drug conjugates for multiple cancers. It has been shown that polymeric NPs have a higher loading capacity for poorly water-soluble drugs, more stability, and more physicochemical properties (solubility, stability) compared to liposomes. The hybrid PM, developed by coating a PEGphospholipid copolymer envelope on a nuclear PLGA NP, has improved therapeutic index with reduced toxicity. ${ }^{62}$ A cisplatin-modified Pt(IV)-based PLGA-PEG NP was also reported with a significantly improved efficacy in breast cancer patients. ${ }^{63}$ Lee and Nan proposed a novel combination of the drug delivery system for HER-2-overexpressing metastatic breast cancer via HER-2-targeted HPMA copolymer conjugates in combination with a tyrosine kinase inhibitor (PKI-166). Their study on targeting HER-2 receptors via extracellular (via TRZ binding) and intracellular (via PKI166 binding) kinase domains suggested the synergistic effect from a drug conjugate delivery system for anticancer activity. ${ }^{24}$ Therefore, a novel drug delivery system using a polymer with different mechanisms of action can bring forth a promising targeted therapy to overcome the limitations of the individual drug.

\section{Dendrimers}

Dendrimers are highly branched macromolecules possessing low polydispersity index. In 1978, Vogtle first described the nanotechnology platforms for drug delivery using dendrimers. ${ }^{64}$ Like other nanocarriers, the biocompatibility and pharmacokinetics of dendrimers are easy to predict and can be controlled. There are various drug platforms that have been synthesized as delivery vehicles such as polyetherhydroxylamine (PEHAM), polyamidoamine (PAMAM), polyesteramine, polypropyleneimine, and polyglycerol. ${ }^{65}$ The biopermeability of cationic PAMAM-NH2 (G0-G4) dendrimers across the biological membranes was evaluated for oral drug delivery which revealed that they crossed the membrane by paracellular and endocytosis pathways. ${ }^{66,67}$ The water solubility and size of dendrimers increased by PEGylation which helped to improve the retention and biodistribution characteristics. Several groups have shown that cell toxicity strongly correlates with the dendrimers end. The surface functional groups of dendrimers are amines that are decorated with protons, benzyloxycarbonyl- or tertbutoxycarbonyl-protecting group's ethylenediamine ligands, or dansyl fluorescence labels. The doxorubicin-containing polyion complex micelle accumulates in the nucleus of drugresistant MCF-7 cells and is also considered to have a potent antiproliferative effect on targeted tumor. ${ }^{68}$ The cytotoxicity of MCF-7 breast cancer cells was examined in vitro using low-generation (G0, G1, and G2) PAMAM-like polymers. ${ }^{69}$ However, dendrimers-drug conjugate has an antineoplastic agent and is covalently attached to the peripheral groups of the dendrimers, and has distinct advantages over drugencapsulated systems. For local delivery in breast cancer, doxorubicin-G4-PAMAM complexes were encapsulated into the liposomes. These were formulated with HEPC and showed enhanced activity towards the MDA-MB435 breast cells compared to the individual dendrimers. ${ }^{65}$ Thus, the methods for delivering the dendrimers-based NPs for transport of drugs into the specific area of malignant cells could be the best approach for delivery of NPs and to treat cancer cells.

\section{Inorganic drug delivery approaches Gold nanoparticles}

GNPs are used in chemotherapy for several cancers. Due to their small size (approximately $130 \mathrm{~nm}$ ) and specificity, they circulate throughout the tumor cells. GNP coating acts as a biomarker for the cancer diagnosis and is used as a probe for transmission electron microscopy and antimicrobial agents There are several methods available for GNP production; the most common is the one involving citrate reduction of gold in water and the Brust-Schiffrin method..$^{70}$ The conjugation of GNPs to transferrin molecules was tested in breast cancer cells, and the results showed higher cellular uptake of transferrin molecules bound to GNPs in comparison to unbound molecules. ${ }^{71}$ PEG-conjugated liposomes were used for anticancer drug delivery. ${ }^{72}$ Balakrishnan et al targeted the breast cancer EGFR/VEGFR-2 signaling pathway using AuNPs-Qu-5, and reported its role in inhibition of migration, invasion, angiogenesis, and metastasis of breast cancer cells. This group has studied significant inhibition of multiple proteins such as p-PI3K, Akt, Snail, Slug, vimentin, N-cadherin, and $\mathrm{p}-\mathrm{GSK} 3 \beta$ with treatment with AuNPs-Qu-5. ${ }^{73}$ Eissa et al investigated 120 patient samples for ER, PR, and HER-2 status and reported that histidine-rich glycoprotein RNAAuNPs had $90 \%$ sensitivity and specificity and can act as a diagnostic marker for breast cancer prognosis. ${ }^{74}$ Another report showed that triple-negative breast cancer MDAMB-231 cells were inhibited by phytochemical compounds such as gallic acid capped with GNPs. ${ }^{75}$ 


\section{SPIO-NPS}

Superparamagnetic iron oxides (SPIOs) are used in tissue repair, immunoassay, and for cellular imaging in a magnetic field. They are also used as magnetic resonance contrast agents, controlling the direction of magnetic force to allow monitoring of the physiological and molecular changes in the body. SPIO nanoparticles (SPIO-NPs) have the ability to control the physical and chemical properties of particles such as their shape, size, and surface chemistry. SPIO-NPs have several applications in detection of inflammatory diseases and targeting of surface markers on tumors. SPIO consists of two components, an iron oxide core and a hydrophilic coating of the magnetic particle biomolecule, which allow it to deliver nano-derived biomolecules in a targeted area. ${ }^{76}$ Biopolymers such as PEG, polyacrylic acid, dextran, alginate, polyethylene imine, and poly (vinyl alcohol) (PVA) are used as coating reagents for the surface stabilization of SPIOs. ${ }^{77}$ They bind to tumor sites for delivery of antibodies, enzymes, proteins, drugs, or nucleotides. The uptake of SPIO-loaded PLA-tocopheryl PEG succinate (SPIO-PNPs) by MCF-7 breast cancer cells was confirmed through TEM in several experiments. ${ }^{78}$ SPIO-targeted biomarkers have been developed for tumor cell imaging and detection. SPIO-Herceptin detects overexpression of HER-2/neu (c-erbB-2) tyrosine kinase receptor in the metastatic breast cancer. ${ }^{79}$ SPIOs most efficiently used in magnetic resonance imaging and macrophage processing. However, knowledge concerning breast cancer and metastatic lymph nodes injection of SPIOs is lacking and needs to be explored. In future, SPIO-NPs could be applied as an effective treatment agent in breast cancer therapy.

\section{Quantum dots (QD)}

QD nanocrystals have a tunable wavelength, high brightness, anti-photo bleach, and optical properties, and are used as probes for many biological and biomedical applications. The conjugation of surface-modified QDs with antibodies, peptides, or other biomolecules enables their application in clinical oncology targeting. Bae et al synthesized a bimodal imaging nanoprobe by conjugating monoclonal antibodies and perfluorocarbon (PFC)/QD nanoemulsions for the detection of surface antigens on breast cancer cells (SK-BR-3, MCF-7, MDA-MB468) and also proposed that PFC/QD nanoemulsion had a great capacity for imaging therapy of tumor cells. ${ }^{80}$ Several studies have shown the potential of QDs usage for various applications, including imaging, cell tracking, immunolabeling, in situ hybridization, and other in vitro- and in vivo-related technologies.

\section{Localized drug delivery approaches}

The current treatment for recurrent breast cancer is based on chemotherapeutic drugs, radiation, or surgery depending on location and the stages of the tumor. Localized drug delivery has more impact as a therapeutic option for earlystage cancers compared to the systemic drug. There are natural (dextran, chitosan, hyaluronic acid, gelatin, collagen polypeptides) and synthetic polymers that are used intratumorally in the cancerous tissue for drug delivery to cure breast cancer ${ }^{81}$ Furthermore, hydrogel formation of the NPs or polymers system, nanofiber with versatile morphology and tensile strength, and intraductal injection using microcatheter enhance the performance of ongoing smart drug delivery therapy.

\section{Nanofibers}

A nanofiber is a cross-linked polymer characterized by tensile strength and chemical nature. Biodegradable polymers such as PEG, PLGA, chitosan, PVA, PLA, polyethylene oxide, and PCL are used for preparing nanofibers for drug delivery applications. Another type of nanofiber, electrospun, was found to be bioactive and biocompatible similar to a human extracellular matrix, which supports diverse cells to grow into fabricated tissues. ${ }^{82}$ A nanofiber-based platform has been prepared to evaluate migration of metastatic breast cancer cells. Curcumin-loaded PCL nanofibers were tested in breast cancer cell line MCF-7, and exhibited $15 \%$ more cytotoxicity compared to the commercial drug. ${ }^{16}$ The use of a nanofiber model could allow testing the efficacy of an anticancer drug in diagnostic tools for multiple malignancies.

\section{Hydrogels}

Hydrogels are water-insoluble molecules, chemically or physically linked into a polymer chain. They allow controlled release of a drug within the body. Drugs enclosed within a hydrogel correspond to swell, diffusion, and control of the chemicals. Hydrogels for tumor cell therapy are developed in the form of microspheres or NPs. They are fabricated using protein and glycosaminoglycan components of breast tissue, which stimulate the growth of human breast cells. The most common endothermal hydrogel was based on chitosan, which is formed in tumor tissue after intratumor injection. ${ }^{83}$ Chitosan hydrogels based on temperature-responsive hydroxyl butyl, poly (vinyl alcohol), thermo sensitive poly (ethylene glycol)-grafted, chitosan chloride/glycerophosphate and chitosan/bifunctional aldehyde have been investigated, but not tested in the preclinical trial for breast cancer 
application. However, only a few of the hydrogels have in situ gelling properties. Another platform for local and sustained delivery with high efficiencies in in vitro and in vivo breast cancer mice model was reported via siRNA encapsulation in oligopeptide-terminated poly $(\beta$-amino ester $)$ NPs. Moreover, sustained delivery was enhanced when NPs were embedded in a hydrogel scaffold. ${ }^{84}$

\section{Intraductal injection}

The molecular and morphological changes that occur in breast ductal epithelium cells are associated with a high risk of breast cancer. Ductal carcinoma in situ is a noninvasive early cancer, occurring in the lining of the breast milk duct, and represents $80 \%$ of breast cancers diagnosed. The use of microcatheter for collecting ductal cells can improve the ductal epithelium cells detection in abnormal breast cells. Ductal lavage procedure using microcatheter has been reported for cytological analysis with high efficiency for collecting breast epithelial cells. A study of 507 women who had a high risk of breast cancer was conducted to evaluate nipple aspirate fluid and ductal lavage and proved that ductal lavage was more sensitive and safer than nipple aspiration..$^{85}$ Moreover, chemotherapy through localized drug delivery was achieved by intraductal injection of chemotherapeutic drugs 5-fluorouracil and estradiol into mammary papilloma for the improvement of the immune response. ${ }^{86}$ Detection of ductal cellular abnormalities can provide additional information to reduce the risk of breast cancer and also help in ongoing drug therapy.

\section{Receptor-based drug delivery approaches}

Breast cancer growths are regulated by multiple receptors, and inhibition at the receptor provides a new avenue for cancer therapy. Studies on receptor targeting are being used in clinical trials in patients with metastatic breast cancer. Although multiple cytotoxic drugs, such as gemcitabine, nab-paclitaxel, doxorubicin, etoposide, and vinorelbine, have been developed, the overall survival rates are still less. ${ }^{87}$ Several studies have focused on receptors HER-2, EGFR, IGF-IR, and VEGFR, which revealed specific targets for breast cancer cells. According to those studies, HER-2 belongs to EGFR family and is poorly differentiated in triple-negative breast cancer; IGF-IR is regulated by tyrosine kinases, whereas VEGFR works as a stimulus for angiogenesis. The receptor-based targeting approach is illustrated in Figure 3.

\section{HER-2}

HER-2 has been reported to be overexpressed in breast cells. It belongs to the EGFR family and strongly correlates with tumorigenesis. Anti-HER-2 therapy using nanocarrier drugs and antibody-directed therapy for the antigen-binding site could be an effective treatment for breast cancer. Trastuzumab $(\mathrm{mAb})$ has shown an overall response rate of $15 \%-30 \%$ against the extracellular domain of HER-2positive breast cancer cells when given individually, but in combination with taxanes or vinorelbine, the response rates were $50 \%-80 \%{ }^{88}$ In a randomized clinical trial Phases II and III, the overall percentage survival and the response rate were demonstrated to be high when combination therapies of trastuzumab with chemotherapeutic drugs were given to breast cancer patients. ${ }^{16}$ Blockade of receptor using inhibitors may improve the treatment of trastuzumab-resistant tumors. A tyrosine kinase inhibitor, such as lapatinib, blocks the expression of EGFR (ErbB1) and HER-2 (ErbB2), which are co-expressed in $30 \%$ of breast cancers. The Phase II trial has shown 33\% response rate after treatment of HER-2-positive metastatic breast cancer with lapatinib. ${ }^{89}$ Another inhibitor gefitinib (an EGFR tyrosine kinase inhibitor) and pertuzumab $(\mathrm{mAb})$ were reported to be able to block the overexpression and hetero-dimerization of HER-2 receptor family. ${ }^{90}$ Moreover, adjuvant therapy of chemotherapeutic drugs can enhance the overall survival rate of breast cancer patients.

\section{EGFR}

Overexpression of EGFR has been reported in poorly differentiated triple-negative and inflammatory breast cancer cells. EGFR gene was identified in the early 1980s, and the clinical interest in the gene began in the late 1990s with the development of inhibitors. ${ }^{91}$ There are several members of EGFR family reported, including EGFR (also known as ErbB1 and HER-1), HER-2 (also known as HER-2/neu and ErbB2), ErbB3 (HER3), and ErbB4 (HER4). Out of these, HER-2 was overexpressed in breast cancer. ${ }^{92,93}$ It has been proven that the EGFR expression was correlated with an increased copy number of the gene and protein overexpression in breast cancer. The increased EGFR gene copy number and protein overexpression were observed in ER-negative, PR-negative, HER-2 negative (triple-negative) breast cancer patients. Although drugs including cetuximab, lapatinib, gefitinib, and others have been developed to target the EGFR, the overall clinical outcome is poor. EGFR signaling and the relationship between triple-negative and inflammatory breast cancer-targeted therapies are the current topic of interest in the field of breast tumor therapy. Several clinical trials 


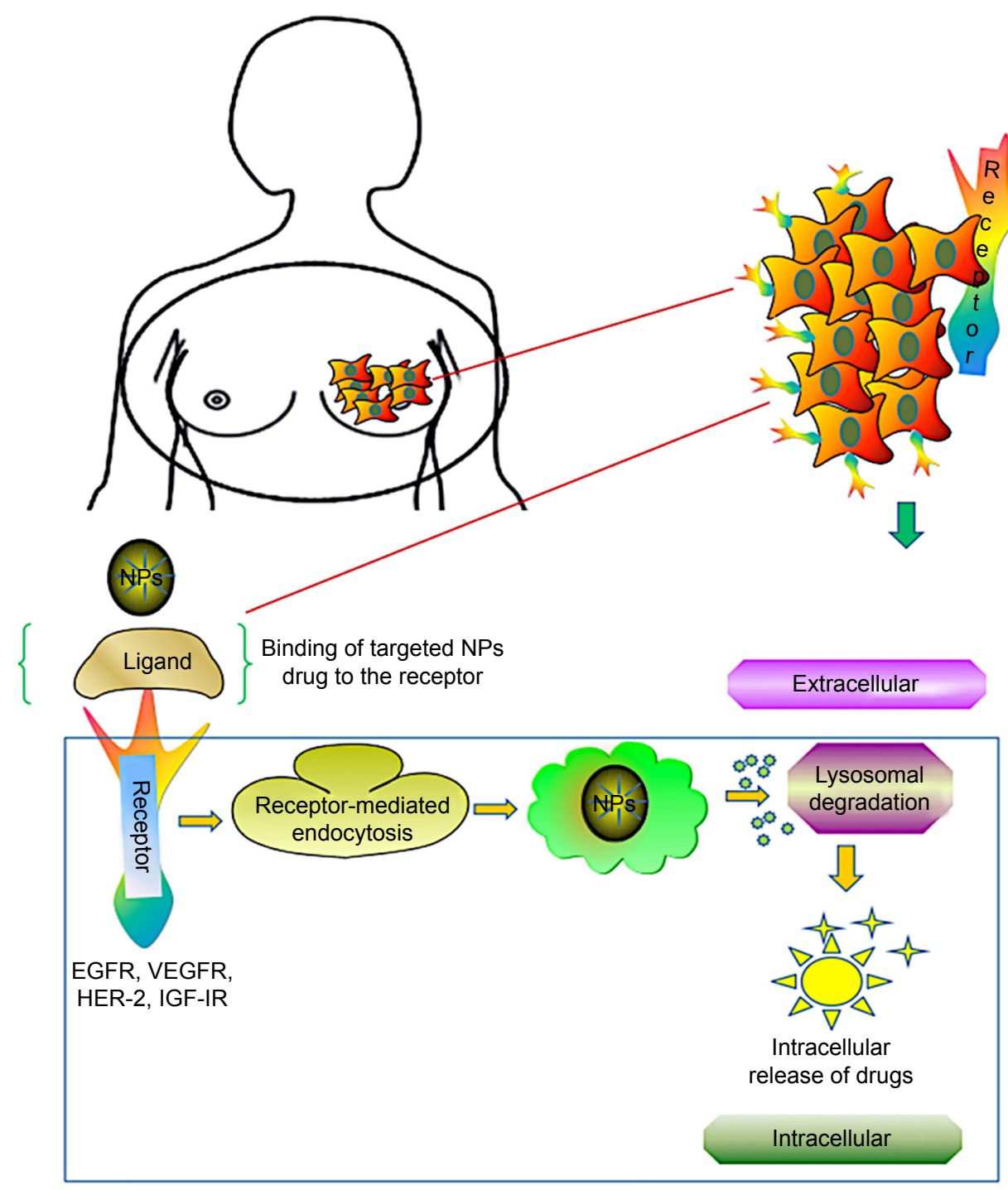

Figure 3 Receptor-mediated drug delivery to metastatic breast cancer cells. Nanocarrier-based drug targeting using receptor-mediated pathways governs the major therapeutic approach for the active sites in tumor cells. Ligand-nanoparticle conjugate binds to the receptors (EGFR, VEGFR, HER-2, IGF-IR) on the membrane, mediates internalization of nanoparticles through endocytosis, and releases the drugs by lysosomal degradation to the active sites of tumor cells.

Abbreviations: EGFR, epidermal growth factor receptor; VEGFR, vascular endothelial growth factor receptor; HER-2, human epidermal growth factor receptor 2; IGF-IR, insulin-like growth factor I receptor; NPs, nanoparticles.

investigating vascular endothelial growth factor (VEGF), EGFR, Src, and mTOR molecular markers, for the treatments of triple-negative breast cancer, are ongoing; other inhibitors of the PI3K/AKT/mTOR pathway for deregulation in triplenegative breast cancer are in early-phase clinical trials.

\section{IGF-IR}

Breast cancer growth is regulated by receptor tyrosine kinases (RTKs), and the inhibition of the receptors, thus, could be the targets for anticancer therapy. The growth and differentiation of normal breast cells are mediated by IGF-IR signaling. Additionally, it stimulates mitogenesis and apoptosis of tumor cells. RTKs contain two domains - intracellular tyrosine kinase domain and extracellular ligand-binding domain. The ligands binding to the IGF-IR activate tyrosine kinases and induce conformational changes. ${ }^{94}$ After activation, antiapoptotic effects of the IGF-IR are mediated via the Akt/PI3K pathways and IGF-IR is overexpressed in many cell types.$^{95}$ RTKs such as IGF-IR and c-erbB-2/HER-2/neu (HER-2/neu) have been reported for the breast cancer cell growth. Inhibition of these RTKs helps in reduction of cell growth and drug development. ${ }^{96}$ Several reports demonstrate the evidence for overexpression and hyperactivation of the IGF-IR in the early stages of breast cancer. ${ }^{97-99}$ The negative expression of IGF-IR, using monoclonal antibodies, antisense IGF-IR, catechols, and transfection methods, 
can inhibit the tumor growth in breast cancer. ${ }^{100,101}$ Nordihydroguaiaretic acid is a phenolic compound and is reported as a direct inhibitor of both IGF-IR and the HER-2/neu receptor in breast tumor cells and induces apoptosis. Thus, negative expression of IGF-IR with a potential inhibitor can play an important role in breast cancer therapy.

\section{VEGF}

VEGF serves as a primary stimulus of angiogenesis when upregulated by various hormones, cytokines, and transforming growth factors. It is associated with the development, progression, and metastasis of breast cancer, through receptors such as VEGFR-2 (also known as flk/kdr), VEGFR-1 (also known as flt), and VEGF-C (homolog of VEGF gene family). VEGF-2 (flk) and VEGF-1 (flt) are expressed on vascular endothelial or non-endothelial cell-specific receptor; ${ }^{102}$ VEGFR-1 (flt) is found on monocytes, whereas VEGF-C receptor (flt-4) is expressed on endothelial cells of lymphatic vessels. ${ }^{103}$ VEGFRs play an important role in the antiapoptotic mechanisms in breast cancer cells. ${ }^{104}$ The receptor-based monoclonal antibodies have been reported to inhibit VEGF activity, which downregulates the growth of tumors and their blood vessels. ${ }^{105}$ The siRNA as well as anti-VEGF antibody therapy is already in clinical trials for regulation of VEGF activity. ${ }^{106}$ Therefore, targeting of endothelial growth factor either alone or in combination with a target agent could be the future therapeutic strategy for metastatic breast cancer.

\section{Conclusion}

Drug carrier systems allow for the controlled release of drugs at the desired sites, thus altering the pharmacokinetics and biodistribution of the drugs. In this sense, nanoparticles are intrinsically advantageous over conventional particles. This study provides an overview of all aspects of drug delivery mechanisms using nanocarriers for metastatic breast cancer treatment. Precise drug release into highly specific targets involves miniaturizing the delivery systems to be much smaller than their targets. It is highly expected that these minute drug delivery system can be realized through the advances in nanotechnology. The integration of nanotechnology products, such as nanoparticles, with therapeutic agents, has recently created a new therapeutic trend that would not otherwise be possible.

\section{Acknowledgments}

The authors thank Ms Angela Wimes for her critical review of the manuscript. This study was supported in part by the National Cancer Institute of the National Institute of Health under Award Number SC1CA193758 and by National Institute of Health under Award Number 5G12MD007602.

\section{Disclosure}

The authors report no potential conflicts of interest in this work.

\section{References}

1. Siegel RL, Miller KD, Jemal A. Cancer statistics, 2016. CA Cancer J Clin. 2016;66(1):7-30.

2. Carty NJ, Foggitt A, Hamilton CR, Royle GT, Taylor I. Patterns of clinical metastasis in breast cancer: an analysis of 100 patients. Eur J Surg Oncol. 1995;21(6):607-608.

3. Grobmyer SR, Zhou G, Gutwein LG, Iwakuma N, Sharma P, Hochwald SN. Nanoparticle delivery for metastatic breast cancer. Nanomedicine. 2012;8 Suppl 1:S21-S30.

4. Davies E, Hiscox S. New therapeutic approaches in breast cancer. Maturitas. 2011;68(2):121-128.

5. Eroles P, Bosch A, Pérez-Fidalgo JA, Lluch A. Molecular biology in breast cancer: intrinsic subtypes and signaling pathways. Cancer Treat Rev. 2012;38(6):698-707.

6. Kreike B, van Kouwenhove M, Horlings H, et al. Gene expression profiling and histopathological characterization of triple-negative/ basal-like breast carcinomas. Breast Cancer Res. 2007;9(5):R65.

7. Singh R, Lillard JW Jr. Nanoparticle-based targeted drug delivery. Exp Mol Pathol. 2009;86(3):215-223.

8. Bangham AD. Liposomes: the Babraham connection. Chem Phys Lipids. 1993;64(1-3):275-285.

9. Zhang S, Chu Z, Yin C, Zhang C, Lin G, Li Q. Controllable drug release and simultaneously carrier decomposition of $\mathrm{SiO} 2$-drug composite nanoparticles. J Am Chem Soc. 2013;135(15):5709-5716.

10. Bhattacharjee H, Balabathula P, Wood GC. Targeted nanoparticulate drug-delivery systems for treatment of solid tumors: a review. Ther Deliv. 2010;1(5):713-734.

11. Beloqui A, Alhouayek M, Carradori D, et al. A mechanistic study on nanoparticle-mediated glucagon-like peptide-1 (GLP-1) secretion from enteroendocrine L cells. Mol Pharm. 2016;13(12):4222-4230.

12. Kafa H, Wang JT, Rubio N, et al. Translocation of LRP1 targeted carbon nanotubes of different diameters across the blood-brain barrier in vitro and in vivo. $J$ Control Release. 2016;225:217-229.

13. Venugopal K, Rather HA, Rajagopal K, et al. Synthesis of silver nanoparticles (Ag NPs) for anticancer activities (MCF 7 breast and A549 lung cell lines) of the crude extract of Syzygium aromaticum. J Photochem Photobiol B. 2017;167:282-289.

14. Khosravian P, Shafiee Ardestani M, Khoobi M, et al. Mesoporous silica nanoparticles functionalized with folic acid/methionine for active targeted delivery of docetaxel. Onco Targets Ther. 2016;9:7315-7330.

15. Johnstone TC, Suntharalingam K, Lippard SJ. The next generation of platinum drugs: targeted Pt(II) agents, nanoparticle delivery, and Pt(IV) prodrugs. Chem Rev. 2016;116(5):3436-3486.

16. Marty M, Cognetti F, Maraninchi D, et al. Randomized phase II trial of the efficacy and safety of trastuzumab combined with docetaxel in patients with human epidermal growth factor receptor 2-positive metastatic breast cancer administered as first-line treatment: the M77001 study group. J Clin Oncol. 2005;23(19):4265-4274.

17. Kontermann RE. Immunoliposomes for cancer therapy. Curr Opin Mol Ther. 2006;8(1):39-45.

18. Milane L, Duan ZF, Amiji M. Pharmacokinetics and biodistribution of lonidamine/paclitaxel loaded, EGFR-targeted nanoparticles in an orthotopic animal model of multi-drug resistant breast cancer. Nanomedicine. 2011;7(4):435-444.

19. Wang Y, Gao S, Ye WH, Yoon HS, Yang YY. Co-delivery of drugs and DNA from cationic core-shell nanoparticles self-assembled from a biodegradable copolymer. Nat Mater. 2006;5(10):791-796. 
20. Nishimura $\mathrm{Y}$, Mieda H, Ishii J, Ogino C, Fujiwara T, Kondo A. Targeting cancer cell-specific RNA interference by siRNA delivery using a complex carrier of affibody-displaying bio-nanocapsules and liposomes. J Nanobiotechnology. 2013;11:19.

21. Bae Y, Diezi TA, Zhao A, Kwon GS. Mixed polymeric micelles for combination cancer chemotherapy through the concurrent delivery of multiple chemotherapeutic agents. J Control Release. 2007;122(3): 324-330.

22. Wong MY, Chiu GN. Liposome formulation of co-encapsulated vincristine and quercetin enhanced antitumor activity in a trastuzumabinsensitive breast tumor xenograft model. Nanomedicine. 2011;7(6): 834-840.

23. Chen Y, Bathula SR, Li J, Huang L. Multifunctional nanoparticles delivering small interfering RNA and doxorubicin overcome drug resistance in cancer. J Biol Chem. 2010;285(29):22639-22650.

24. Lee JH, Nan A. Combination drug delivery approaches in metastatic breast cancer. J Drug Deliv. 2012;2012:915375.

25. Robert N, Leyland-Jones B, Asmar L, et al. Randomized phase III study of trastuzumab, paclitaxel, and carboplatin compared with trastuzumab and paclitaxel in women with HER-2-overexpressing metastatic breast cancer. J Clin Oncol. 2006;24(18):2786-2792.

26. Bartsch R, Wenzel C, Altorjai G, et al. Capecitabine and trastuzumab in heavily pretreated metastatic breast cancer. J Clin Oncol. 2007; 25(25):3853-3858.

27. Baselga J, Trigo JM, Bourhis J, et al. Phase II multicenter study of the antiepidermal growth factor receptor monoclonal antibody cetuximab in combination with platinum-based chemotherapy in patients with platinum-refractory metastatic and/or recurrent squamous cell carcinoma of the head and neck. J Clin Oncol. 2005;23(24): $5568-5577$

28. Cameron D, Casey M, Oliva C, Newstat B, Imwalle B, Geyer CE. Lapatinib plus capecitabine in women with HER-2-positive advanced breast cancer: final survival analysis of a phase III randomized trial. Oncologist. 2010;15(9):924-934.

29. Di Leo A, Gomez HL, Aziz Z, et al. Phase III, double-blind, randomized study comparing lapatinib plus paclitaxel with placebo plus paclitaxel as first-line treatment for metastatic breast cancer. J Clin Oncol. 2008; 26(34):5544-5552.

30. Moy B, Goss PE. Lapatinib-associated toxicity and practical management recommendations. Oncologist. 2007;12(7):756-765.

31. Ademuyiwa FO, Miller KD. Incorporation of antiangiogenic therapies in the treatment of metastatic breast cancer. Clin Breast Cancer. 2008; 8 Suppl 4:S151-S156.

32. Gatzemeier U, Pluzanska A, Szczesna A, et al. Phase III study of erlotinib in combination with cisplatin and gemcitabine in advanced non-small-cell lung cancer: the Tarceva Lung Cancer Investigation Trial. J Clin Oncol. 2007;25(12):1545-1552.

33. Joensuu H, Holli K, Heikkinen M, et al. Combination chemotherapy versus single-agent therapy as first- and second-line treatment in metastatic breast cancer: a prospective randomized trial. J Clin Oncol. 1998;16(12):3720-3730.

34. Bria E, Giannarelli D, Felici A, et al. Taxanes with anthracyclines as first-line chemotherapy for metastatic breast carcinoma. Cancer. 2005; 103(4):672-679.

35. Albain KS, Nag SM, Calderillo-Ruiz G, et al. Gemcitabine plus Paclitaxel versus Paclitaxel monotherapy in patients with metastatic breast cancer and prior anthracycline treatment. J Clin Oncol. 2008;26(24): 3950-3957.

36. Burzykowski T, Buyse M, Piccart-Gebhart MJ, et al. Evaluation of tumor response, disease control, progression-free survival, and time to progression as potential surrogate end points in metastatic breast cancer. J Clin Oncol. 2008;26(12):1987-1992.

37. Chan S, Romieu G, Huober J, et al. Phase III study of gemcitabine plus docetaxel compared with capecitabine plus docetaxel for anthracycline-pretreated patients with metastatic breast cancer. J Clin Oncol. 2009;27(11):1753-1760.
38. O'Shaughnessy J, Miles D, Vukelja S, et al. Superior survival with capecitabine plus docetaxel combination therapy in anthracyclinepretreated patients with advanced breast cancer: phase III trial results. J Clin Oncol. 2002;20(12):2812-2823.

39. Wang J, Fan Y, Xu B. Ixabepilone plus capecitabine for Chinese patients with metastatic breast cancer progressing after anthracycline and taxane treatment. Cancer Chemother Pharmacol. 2010;66(3):597-603.

40. Bonadonna G, Valagussa P, Moliterni A, Zambetti M, Brambilla C. Adjuvant cyclophosphamide, methotrexate, and fluorouracil in nodepositive breast cancer: the results of 20 years of follow-up. $N$ Engl $J$ Med. 1995;332(14):901-906.

41. Hainsworth JD. Mitoxantrone, 5-fluorouracil and high-dose leucovorin (NFL) in the treatment of metastatic breast cancer: randomized comparison to cyclophosphamide, methotrexate and 5-fluorouracil (CMF) and attempts to improve efficacy by adding paclitaxel. Eur J Cancer Care (Engl). 1997;6(4 Suppl):4-9.

42. Ackland SP, Anton A, Breitbach GP, et al. Dose-intensive epirubicinbased chemotherapy is superior to an intensive intravenous cyclophosphamide, methotrexate, and fluorouracil regimen in metastatic breast cancer: a randomized multinational study. J Clin Oncol. 2001;19(4): 943-953.

43. Blackwell KL, Burstein HJ, Storniolo AM, et al. Randomized study of Lapatinib alone or in combination with trastuzumab in women with ErbB2-positive, trastuzumab-refractory metastatic breast cancer. J Clin Oncol. 2010;28(7):1124-1130.

44. Zhang Y, Huang Y, Li S. Polymeric micelles: nanocarriers for cancertargeted drug delivery. AAPS PharmSciTech. 2014;15(4):862-871.

45. Mohajer G, Lee ES, Bae YH. Enhanced intercellular retention activity of novel $\mathrm{pH}$-sensitive polymeric micelles in wild and multidrug resistant MCF-7 cells. Pharm Res. 2007;24(9):1618-1627.

46. Yuan Y, Cai T, Xia X, Zhang R, Chiba P, Cai Y. Nanoparticle delivery of anticancer drugs overcomes multidrug resistance in breast cancer. Drug Deliv. 2016;23(9):3350-3357.

47. Sadat SM, Saeidnia S, Nazarali AJ, Haddadi A. Nano-pharmaceutical formulations for targeted drug delivery against HER2 in breast cancer. Curr Cancer Drug Targets. 2015;15(1):71-86.

48. Lee AL, Wang Y, Cheng HY, Pervaiz S, Yang YY. The co-delivery of paclitaxel and Herceptin using cationic micellar nanoparticles. Biomaterials. 2009;30(5):919-927.

49. Lee KS, Chung HC, Im SA, et al. Multicenter phase II trial of Genexol-PM, a Cremophor-free, polymeric micelle formulation of paclitaxel, in patients with metastatic breast cancer. Breast Cancer Res Treat. 2008; 108(2):241-250.

50. Wang AZ, Langer R, Farokhzad OC. Nanoparticle delivery of cancer drugs. Annu Rev Med. 2012;63:185-198.

51. Szulc J, Dudzik M, Woyczikowski B, Sznitowska M, Janicki S. [Liposomes - therapeutic progress and technological problems]. Pol Merkur Lekarski. 2002;12(68):164-168. Polish [with English abstract].

52. Kalepu S, Nekkanti V. Insoluble drug delivery strategies: review of recent advances and business prospects. Acta Pharm Sin B. 2015;5(5): $442-453$.

53. Kang DI, Kang HK, Gwak HS, Han HK, Lim SJ. Liposome composition is important for retention of liposomal rhodamine in P-glycoproteinoverexpressing cancer cells. Drug Deliv. 2009;16(5):261-267.

54. Straubinger RM, Papahadjopoulos D. Liposomes as carriers for intracellular delivery of nucleic acids. Methods Enzymol. 1983;101:512-527.

55. Sharma A, Straubinger RM, Ojima I, Bernacki RJ. Antitumor efficacy of taxane liposomes on a human ovarian tumor xenograft in nude athymic mice. J Pharm Sci. 1995;84(12):1400-1404.

56. Sharma A, Mayhew E, Bolcsak L, et al. Activity of paclitaxel liposome formulations against human ovarian tumor xenografts. Int $J$ Cancer. 1997;71(1):103-107.

57. Suk JS, Xu Q, Kim N, Hanes J, Ensign LM. PEGylation as a strategy for improving nanoparticle-based drug and gene delivery. Adv Drug Deliv Rev. 2016;99(Pt A):28-51. 
58. Yang T, Cui FD, Choi MK, et al. Enhanced solubility and stability of PEGylated liposomal paclitaxel: in vitro and in vivo evaluation. Int $J$ Pharm. 2007;338(1-2):317-326.

59. Dhankhar R, Vyas SP, Jain AK, Arora S, Rath G, Goyal AK. Advances in novel drug delivery strategies for breast cancer therapy. Artif Cells Blood Substit Immobil Biotechnol. 2010;38(5):230-249.

60. Kullberg M, Owens JL, Mann K. Listeriolysin O enhances cytoplasmic delivery by Her-2 targeting liposomes. J Drug Target. 2010;18(4): 313-320.

61. Wong MY, Chiu GN. Simultaneous liposomal delivery of quercetin and vincristine for enhanced estrogen-receptor-negative breast cancer treatment. Anticancer Drugs. 2010;21(4):401-410.

62. Sengupta S, Eavarone D, Capila I, et al. Temporal targeting of tumour cells and neovasculature with a nanoscale delivery system. Nature. 2005;436(7050):568-572.

63. Dhar S, Kolishetti N, Lippard SJ, Farokhzad OC. Targeted delivery of a cisplatin prodrug for safer and more effective prostate cancer therapy in vivo. Proc Natl Acad Sci U S A. 2011;108(5):1850-1855.

64. Madaan K, Kumar S, Poonia N, Lather V, Pandita D. Dendrimers in drug delivery and targeting: drug-dendrimer interactions and toxicity issues. J Pharm Bioallied Sci. 2014;6(3):139-150.

65. Wolinsky JB, Grinstaff MW. Therapeutic and diagnostic applications of dendrimers for cancer treatment. Adv Drug Deliv Rev. 2008;60(9): 1037-1055.

66. Kitchens KM, El-Sayed ME, Ghandehari H. Transepithelial and endothelial transport of poly (amidoamine) dendrimers. Adv Drug Deliv Rev. 2005;57(15):2163-2176.

67. Northfelt DW, Dezube BJ, Thommes JA, et al. Pegylated-liposomal doxorubicin versus doxorubicin, bleomycin, and vincristine in the treatment of AIDS-related Kaposi's sarcoma: results of a randomized phase III clinical trial. J Clin Oncol. 1998;16(7):2445-2451.

68. Lu HL, Syu WJ, Nishiyama N, Kataoka K, Lai PS. Dendrimer phthalocyanine-encapsulated polymeric micelle-mediated photochemical internalization extends the efficacy of photodynamic therapy and overcomes drug-resistance in vivo. J Control Release. 2011;155(3): 458-464.

69. Fuchs S, Kapp T, Otto H, et al. A surface-modified dendrimer set for potential application as drug delivery vehicles: synthesis, in vitro toxicity, and intracellular localization. Chemistry. 2004;10(5):1167-1192.

70. Jain S, Hirst DG, O'Sullivan JM. Gold nanoparticles as novel agents for cancer therapy. Br J Radiol. 2012;85(1010):101-113.

71. Li JL, Wang L, Liu XY, et al. In vitro cancer cell imaging and therapy using transferrin-conjugated gold nanoparticles. Cancer Lett. 2009;274(2):319-326.

72. Yang PH, Sun X, Chiu JF, Sun H, He QY. Transferrin-mediated gold nanoparticle cellular uptake. Bioconjug Chem. 2005;16(3):494-496.

73. Balakrishnan S, Bhat FA, Raja Singh P, et al. Gold nanoparticleconjugated quercetin inhibits epithelial-mesenchymal transition, angiogenesis and invasiveness via EGFR/VEGFR-2-mediated pathway in breast cancer. Cell Prolif. 2016;49(6):678-697.

74. Eissa S, Azzazy HM, Matboli M, Shawky SM, Said H, Anous FA. The prognostic value of histidine-rich glycoprotein RNA in breast tissue using unmodified gold nanoparticles assay. Appl Biochem Biotechnol. 2014;174(2):751-761.

75. Chen YJ, Lee YC, Huang CH, Chang LS. Gallic acid-capped gold nanoparticles inhibit EGF-induced MMP-9 expression through suppression of p300 stabilization and NFKB/c-Jun activation in breast cancer MDA-MB-231 cells. Toxicol Appl Pharmacol. 2016;310:98-107.

76. Gupta AK, Gupta M. Synthesis and surface engineering of iron oxide nanoparticles for biomedical applications. Biomaterials. 2005;26(18): 3995-4021.

77. Wang YX, Xuan S, Port M, Idee JM. Recent advances in superparamagnetic iron oxide nanoparticles for cellular imaging and targeted therapy research. Curr Pharm Des. 2013;19(37):6575-6593.

78. Ahmed M, Douek M. The role of magnetic nanoparticles in the localization and treatment of breast cancer. Biomed Res Int. 2013;2013:281230.
79. Thorek DL, Chen AK, Czupryna J, Tsourkas A. Superparamagnetic iron oxide nanoparticle probes for molecular imaging. Ann Biomed Eng. 2006;34(1):23-38.

80. Bae PK, Chung BH. Multiplexed detection of various breast cancer cells by perfluorocarbon/quantum dot nanoemulsions conjugated with antibodies. Nano Converg. 2014;1(1):23.

81. Wolinsky JB, Colson YL, Grinstaff MW. Local drug delivery strategies for cancer treatment: gels, nanoparticles, polymeric films, rods, and wafers. J Control Release. 2012;159(1):14-26.

82. Jayakumar R, Prabaharan M, Nair SV, Tamura H. Novel chitin and chitosan nanofibers in biomedical applications. Biotechnol Adv. 2010; 28(1):142-150.

83. Han HD, Mora EM, Roh JW, et al. Chitosan hydrogel for localized gene silencing. Cancer Biol Ther. 2011;11(9):839-845.

84. Segovia N, Pont M, Oliva N, Ramos V, Borrós S, Artzi N. Hydrogel doped with nanoparticles for local sustained release of siRNA in breast cancer. Adv Healthc Mater. 2015;4(2):271-280.

85. Dooley WC, Ljung BM, Veronesi U, et al. Ductal lavage for detection of cellular atypia in women at high risk for breast cancer. $J$ Natl Cancer Inst. 2001;93(21):1624-1632.

86. Dave K, Averineni R, Sahdev P, Perumal O. Transpapillary drug delivery to the breast. PLoS One. 2014;9(12):e115712.

87. Lu RM, Chen MS, Chang DK, et al. Targeted drug delivery systems mediated by a novel peptide in breast cancer therapy and imaging. PLoS One. 2013;8(6):e66128.

88. Montemurro F, Aglietta M. Incorporating trastuzumab into the neoadjuvant treatment of HER2-overexpressing breast cancer. Clin Breast Cancer. 2005;6(1):77-80.

89. Valabrega G, Montemurro F, Aglietta M. Trastuzumab: mechanism of action, resistance and future perspectives in HER2-overexpressing breast cancer. Ann Oncol. 2007;18(6):977-984.

90. Agus DB, Akita RW, Fox WD, et al. Targeting ligand-activated ErbB2 signaling inhibits breast and prostate tumor growth. Cancer Cell. 2002;2(2):127-137.

91. Shimizu N, Behzadian MA, Shimizu Y. Genetics of cell surface receptors for bioactive polypeptides: binding of epidermal growth factor is associated with the presence of human chromosome 7 in human-mouse cell hybrids. Proc Natl Acad Sci U S A. 980;77(6):3600-3604.

92. Burness ML, Grushko TA, Olopade OI. Epidermal growth factor receptor in triple-negative and basal-like breast cancer: promising clinical target or only a marker? Cancer J. 2010;16(1):23-32.

93. Guérin M, Gabillot M, Mathieu MC, et al. Structure and expression of c-erbB-2 and EGF receptor genes in inflammatory and non-inflammatory breast cancer: prognostic significance. Int J Cancer. 1989;43(2): 201-208.

94. Morin MJ. From oncogene to drug: development of small molecule tyrosine kinase inhibitors as anti-tumor and anti-angiogenic agents. Oncogene. 2000;19(56):6574-6583.

95. Kulik G, Klippel A, Weber MJ. Antiapoptotic signalling by the insulinlike growth factor I receptor, phosphatidylinositol 3-kinase, and Akt. Mol Cell Biol. 1997;17(3):1595-1606.

96. Youngren JF, Gable K, Penaranda C, et al. Nordihydroguaiaretic acid (NDGA) inhibits the IGF-1 and c-erbB2/HER2/neu receptors and suppresses growth in breast cancer cells. Breast Cancer Res Treat. 2005; 94(1):37-46.

97. Arteaga CL, Kitten LJ, Coronado EB, et al. Blockade of the type I somatomedin receptor inhibits growth of human breast cancer cells in athymic mice. J Clin Invest. 1989;84(5):1418-1423.

98. Surmacz E. Function of the IGF-I receptor in breast cancer. $J$ Mammary Gland Biol Neoplasia. 2000;5(1):95-105.

99. Khandwala HM, McCutcheon IE, Flyvbjerg A, Friend KE. The effects of insulin-like growth factors on tumorigenesis and neoplastic growth. Endocr Rev. 2000;21(3):215-244.

100. Prager D, Li HL, Asa S, Melmed S. Dominant negative inhibition of tumorigenesis in vivo by human insulin-like growth factor I receptor mutant. Proc Natl Acad Sci U S A. 1994;91(6):2181-2185. 
101. Sachdev D, Li SL, Hartell JS, Fujita-Yamaguchi Y, Miller JS, Yee D. A chimeric humanized single-chain antibody against the type I insulinlike growth factor (IGF) receptor renders breast cancer cells refractory to the mitogenic effects of IGF-I. Cancer Res. 2003;63(3):627-635.

102. Ferrara N, Gerber HP, LeCouter J. The biology of VEGF and its receptors. Nat Med. 2003;9(6):669-676.

103. Kinoshita J, Kitamura K, Kabashima A, Saeki H, Tanaka S, Sugimachi K. Clinical significance of vascular endothelial growth factor-C (VEGF-C) in breast cancer. Breast Cancer Res Treat. 2001; 66(2):159-164.
104. Pidgeon GP, Barr MP, Harmey JH, Foley DA, Bouchier-Hayes DJ. Vascular endothelial growth factor (VEGF) upregulates BCL-2 and inhibits apoptosis in human and murine mammary adenocarcinoma cells. Br J Cancer. 2001;85(2):273-278.

105. Valtola R, Salven P, Heikkilä P, et al. VEGFR-3 and its ligand VEGF-C are associated with angiogenesis in breast cancer. Am J Pathol. 1999; 154(5):1381-1390.

106. Zhang J, Wu YO, Xiao L, Li K, Chen LL, Sirois P. Therapeutic potential of RNA interference against cellular targets of HIV infection. Mol Biotechnol. 2007;37(3):225-236.

\section{Publish your work in this journal}

The International Journal of Nanomedicine is an international, peerreviewed journal focusing on the application of nanotechnology in diagnostics, therapeutics, and drug delivery systems throughout the biomedical field. This journal is indexed on PubMed Central, MedLine, CAS, SciSearch $®$, Current Contents ${ }^{\circledR} /$ Clinical Medicine,
Journal Citation Reports/Science Edition, EMBase, Scopus and the Elsevier Bibliographic databases. The manuscript management system is completely online and includes a very quick and fair peer-review system, which is all easy to use. Visit http://www.dovepress.com/ testimonials.php to read real quotes from published authors. 